\title{
Beyond the Legend: \\ Uncovering the Historical Circumstances Behind the Rescue of the Danish Jews \\ Ellen Keith
}

\begin{abstract}
:
Denmark is one of the only European countries that can speak of its involvement in the Holocaust with some sense of pride. In October of 1943, the Danes pulled off a substantial rescue mission during which they led the majority of the Danish Jews to safety in Sweden. Traditional representations of this event attribute its success to the outstanding moral character of the Danes. This paper challenges this popular view and explores a variety of factors which together facilitated the rescue of the Danish Jews.
\end{abstract}

The Nazi deportation of the Jews from occupied Denmark was scheduled to occur on October 1-2, 1943. However, in the days preceding the operation, the Danish public learned about these deportation plans, which were designed to relocate the Jews to concentration camps. The Danes secretly worked with the Jewish community to coordinate a mass escape to Sweden. By the end of October, the Nazis had arrested less than $5 \%$ of the Jewish population in Denmark. ${ }^{202}$ In the years following the Holocaust, numerous historians, including Leni Yahil and Samuel Abrahamsen, credited the Jewish rescue to the strong moral and ethical values of the Danish people and criticized

202 The details of the escape will not be discussed in detail in this study. For a greater understanding of the course of events (and further statistics regarding the rescue), please see: Saul S. Friedman, "Righteous Gentiles: Denmark and Norway," in A History of the Holocaust (Middlesex, England: Vallentine Mitchell, 2004), 325. 
other nations for failing to react in the same way. ${ }^{203}$ This traditional account of the rescue depicts the Danes as the archetypal heroes in a black-and-white story of good and evil. writer Harold Flender even argues that the rescue of the Danish Jews represents "a single beam of light from an otherwise dark continent." 204 Is this simplistic view accurate, or are there additional factors that facilitated the escape of the Danish Jews? Although the Danish response to the Holocaust was unique, the idea that this reaction should be attributed solely to the character of the Danes is a romanticized and outdated view that is no longer accepted at an academic level. In addition, the position of the Danish government, the behaviour of the Nazis in Denmark and good timing created the necessary opportunities for the rescue. This paper will separate historical events and myth by discussing the importance of external factors in the rescue effort

203 According the Gunnar S. Paulsson, Leni Yahil emphasized the character of the Danes and their ability to "stand the test of the Holocaust," in her book, The Rescue of Danish Jewry. However, Yahil later modified her view of the Danish rescue in, The Holocaust: The Fate of European Jewry. (This study relies on her later work). At the same time, important Jewish figures such as Moshe Bejski, and Julius Margolinsky have glorified the rescue of the Danish Jews. Yahil, Abrahamsen, Bejski and Margolinsky are all quoted in: Gunnar S. Paulsson, "The 'Bridge over the Oresund': The Historiography on the Expulsion of the Jews from Nazi-Occupied Denmark," Journal of Contemporary History 30, no. 3 (I995): 43I-2.

204 Harold Flender, as quoted in: Paulsson, "The 'Bridge over the Oresund'": 43I-2. 
The dominance of the Lutheran Church and democratic traditions in Denmark created a set of shared values and ideology for the Danes. ${ }^{205}$ As the state church in Denmark, the Lutheran Church played a primary role in the development of Danish morals and the rescue of the Danish Jews. In the nineteenth century, the Christian thinker N.F.S. Grundtvig urged Danes to practice livkunst: "the art of living and caring for others", regardless of religious and racial differences. ${ }^{206}$ Lutheran ministers emphasized Grundtvig's philosophy during the early years of occupation. When the deportations began, the Danish Lutheran ministers signed a letter which affirmed their support for the Jews and encouraged Christians to help their Jewish neighbours. The letter stated:

Despite different religious views, we shall struggle to ensure the continued guarantee to our Jewish brothers and sisters of the same freedom we ourselves treasure more than life itself. ${ }^{207}$

The ministers also made reference to the Danish constitution, arguing that Nazi actions contradicted constitutional ideas of equality and "the understanding of justice [that was] rooted in the

205 The Rescue of the Danish Jews: Moral Courage Under Stress, ed. Leo Goldberger (New York: New York University Press, 1987), 187.

206 Although this term was actually coined by Samuel Abrahamsen, the idea of livkunst is attributed to Gruntvig. Friedman, Righteous Gentiles: Denmark and Norway, 320.

207 Contents of this letter can be found in: Ibid., 324; Thorsten Wagner, "Belated Heroism: The Danish Lutheran Church and the Jews," in Antisemitism, Christian Ambivalence, and the Holocaust, ed. Kevin P. Spicer. Anonymous (Bloomington, Indiana: Indiana University Press, 2007), 5. 
Danish people." ${ }^{208}$ A sense of justice and democratic ideology was interconnected with the religious morals of the Danes. Danes regarded Nazism and anti-Semitic legislation as threats to their democratic system. ${ }^{209}$ According to historian Leni Yahil, the defence of democratic ideals actually took precedence over the practice of moral values. She asserts "for the Danes...the Jewish question was a political and not a humanitarian question." 210 Historian Thorsten Wagner agrees, arguing the Danes primarily saw the rescue of the Jews as an opportunity to limit the level of national collaboration and to resist the growing loss of Danish sovereignty. ${ }^{211}$ Thus, these actions were not completely altruistic; the defence of democracy was beneficial to Jews and gentiles alike. At this time, it is important to recognize that not all Danes played a positive role in the rescue movement. Some Danes betrayed hidden Jews, others used the escape as an opportunity for economic benefit, and the large majority did not participate at all. ${ }^{212}$ Therefore, although the

208 lbid., 5.

209 The Danes were not strong supporters of Nazi or fascist ideology. In March 1943, the Danish fascist parties won only $5 \%$ of the vote. For this, and other information on the democratic system, see: Friedman, Righteous Gentiles: Denmark and Norway, 321.; Hans Kirchhoff, "Denmark: A Light in the Darkness of the Holocaust? A Reply to Gunnar S. Paulsson," Journal of Contemporary History 30, no. 3 (1995): 466.

210 Hannah Arendt, Eichmann in Jerusalem: A Report on the Banality of Evil, 5ed. (New York: Penguin Classics, 1963), 179.

211 Wagner, Belated Heroism: The Danish Lutheran Church and the Jews, 21.

212 For example, an informer betrayed 60 Jews that were hiding at Gilleleje Church in Copenhagen. See: Paulsson, The 'Bridge over the Oresund': The Historiography on the Expulsion of the Jews from Nazi-Occupied Denmark, 460.; The Rescue of the Danish Jews: Moral Courage Under Stress, 8. 
character of Danish society helped shape the Danes' reaction, this reaction was neither entirely selfless nor homogenous. The morals of the Danes should not be considered the defining factor for the uniqueness of the Danish response to the so-called "Jewish Problem."

The term "Jewish Problem" is actually difficult to apply to this situation; to all appearances there was no perceived Jewish Problem in Denmark. At the turn of the twentieth century, it would have been difficult to pick out a Jew on the streets of Copenhagen. The Jewish community was small, and highly assimilated. Moreover, Danish Jews had possessed equal citizenship rights since 1849. Despite this, there was still some religious-based anti-Semitism in Denmark. Aggressive anti-Semitism, (such as blood libel cases and ghettos), and racial anti-Semitism never appeared in Denmark. However, stereotyping and basic prejudices remained up until the Second World War. ${ }^{213}$ Under German occupation, Danes began to relate anti-Semitism to collaboration and by 1943 anti-Semitism had taken on a new meaning with both national and international implications.

The Jews in the Netherlands were also highly assimilated and experienced a relatively low level of

213 Wagner, Belated Heroism: The Danish Lutheran Church and the Jews, 9-I3. 
antisemitism. Like the Danes, many Dutch people also showed concern over the fate of their Jews. However, only $25 \%$ of the Dutch Jewish population survived the Holocaust. Despite this seemingly low percentage, the number that survived actually amounted to 35,000 Jews. In contrast, the small size of the Jewish community in Denmark made it easier to save a large portion of the population. Approximately 7,200 Danish Jews escaped to Sweden, out of a total population of $7,800 . .^{214}$ The bulk of the Jewish population in Denmark was comprised of the descendents of Sephardic immigration in the seventeenth and eighteenth centuries. However, by 1943, 1,500 of the Danish Jews were relatively recent refugees. Events in the early twentieth century, such as the Russian Revolutions and Hitler's rise to power, had driven some Eastern Jewish refugees to Denmark. The arrival of these refugees created two distinct subgroups within the Jewish community: the original, assimilated Jews, and the new, orthodox Eastern Jews. ${ }^{215}$ Some of these recent refugees were Zionists

214 Statistics for the Jewish population in Denmark vary. The number 7,800 includes an estimated I,300 children of mixed marriages. 7,200 of the 7,800 Jews escaped to Sweden, 464 were sent to Theresienstadt, and the rest either remained hidden in Denmark, drowned, or committed suicide. For statistics on the Dutch and Danish Jews, see: Ibid., xx.; Leni Yahil, The Holocaust: The Fate of European Jewry, 1932-1945, trans. Ina Friedman and Haya Galai. (New York and Oxford: Oxford University Press, 1990), 574.

215 For tensions between the groups see: Andrew Buckser, "Group Identities and the Construction of the 1943 Rescue of the Danish Jews," Ethnology 37, no. 3 (1998): 416.; The Rescue of the Danish Jews: Moral Courage Under Stress, 58-6I. 
and pushed for either escape or action against the Germans during the occupation. The assimilated Jews considered Zionism a threat to their peaceful coexistence with the gentiles and urged the Eastern refugees to assimilate.

Because the assimilated Jews held most of the power in the Jewish community, the Danish Jews were able to maintain a low profile during the early years of occupation. The Jewish community stopped production of the Jewish newspaper, disbanded most Jewish organizations, and worked to discourage escape attempts. Thus, the small and assimilated nature of the Jewish community allowed the Jews to remain relatively invisible until the summer of 1943. In return for their passivity, the Danish government refused to pass antisemitic legislation and protected all of the Jews in Denmark, including the refugees. ${ }^{216}$

This protection was vital to the survival of the Jews, but it was only possible because of the particular status of the Danish wartime government. After surrendering to the Germans on April $9^{\text {th }}, 1940$, Denmark became the only country in occupied Europe allowed to keep its own government, foreign

216 Yahil, The Holocaust: The Fate of European Jewry, 1932-1945, 176.; Friedman, Righteous Gentiles: Denmark and Norway, 322.; Arendt, Eichmann in Jerusalem: A Report on the Banality of Evil, 172. 
offices abroad, and army. There are numerous reasons why Denmark was granted this special status: the Danes controlled the access to the Baltic, acted as middlemen for trade with Sweden, and were seen by the German Nazis to have Nordic blood. Regardless of the reasons, Denmark's status as a model protectorate provided the Jews with a temporary degree of insulation against Nazi policy. Until late 1943, relations with Germany were based on a "cooperation policy" (Samarbejdspolitik) and remained largely diplomatic. ${ }^{217}$ This policy of cooperation and compromise had its negative side. In 1941, Danish communists were interned in Denmark, and over the course of the war, twentyone stateless Jews were expelled from Denmark to Germany. ${ }^{218}$ Though the government thought it better to provide concessions, these examples illustrate how Denmark did not always act in favour of the Jewish community. As Prime Minister Thorvald Stauning explained, "We [the Danish government] will be forced to do many things for which people will afterward spit at us, if we are to bring Denmark unscathed through this period." 219

\footnotetext{
217 Bent Blüdnikow and Vilhjálmur Örn Vilhjálmsson, "Rescue, Expulsion, and Collaboration: Denmark's Difficulties with its World War II Past," Jewish Political Studies Review 18, no. 3; Friedman, Righteous Gentiles: Denmark and Norway, 318.; Gunnar Leistikow, “Denmark Under the Nazi Heel," Foreign Affairs 2I, no. 2 (1943): 344-6.

218 Ibid., 29.; Blüdnikow and Vilhjálmsson, Rescue, Expulsion, and Collaboration: Denmark's Difficulties with its World War II Past, 219 Friedman, Righteous Gentiles: Denmark and Norway, 318.
} 
As political theorist Hannah Arendt observes, the government's refusal to pass discriminatory legislation and deport refugees meant that "[n]one of the preparatory moves, so important for the bureaucracy of murder, could be carried out...."220 Leading Nazi officials were frustrated by the lack of progress in Denmark. In August 1943, civil unrest led to a Nazi-declared state of emergency. The Nazis used this opportunity to dissolve the Danish government and arrange deportation plans. While the government faltered in some areas, the Prime Minister and his cabinet remained steadfast in their determination to prevent anti-Semitic legislation. The lack of anti-Semitic laws in Denmark (such as the introduction of yellow badges, ghettos, and Judenräte), meant that Jews were not easily identifiable. The deportation process was further deterred by the government's refusal to hand over the Eastern refugees. The protection of refugees was uncommon in occupied Europe, but in Denmark the government insisted that the Germans could no longer lay claim on and deport the refugees, because the Nazis had declared them to be stateless.

220 Arendt, Eichmann in Jerusalem: A Report on the Banality of Evil, 172. 
In October, the Nazis caught and deported 464 Jews to Theresienstadt concentration camp. Even after these deportations, the Nazis still depended on the cooperation of the Danish civil administrators in order to run the country. Using this to their advantage, Danish officials pushed for better conditions for the Danish Jews in Theresienstadt. They arranged care packages for the Jews and ensured that none of their countrymen were sent to death camps. Consequently, the Danish Jews became "the aristocrats of the paradise ghetto," and all but 51 of the Danish Jews eventually returned from Theresienstadt. ${ }^{221}$ However, the dissolution of the Danish government in 1943 illustrates that the government itself was in an unstable position. Both the stability of the Danish government and the security of the Jews relied on the complicity of the Nazi officials in Denmark.

This complicity of Nazi officials removed an essential aspect of the deportation plan - the

- Editor's Note: Theresienstadt's history as concentration camp is complex and requires further study. During World War II, it was for a time a 'model' concentration camp used by the Nazis as an example for visitation by the Red Cross. While the Danes demanded that the Red Cross be given visitation rights into the camp, the Nazis altered conditions to give the false impression that they humanely treated the inmates of Theresienstatd. Consequently, Theresienstadt became a tool of propaganda as conditions were disproportionately better in Theresienstadt as compared to other Nazi concentration camps. For more information see a basic study in "Theresienstadt," Encyclopædia

Britannica,http://www.britannica.com.login.ezproxy.library.ualberta.ca/EBchecked/to pic/591290/Theresienstadt (accessed December 7, 2010).

221 Friedman, Righteous Gentiles: Denmark and Norway, 326. 
element of surprise. Until late September 1943, Nazi officials in Denmark denied any impending deportation plans. As previously stated, the efforts of the Danish government had prevented the necessary preparations for deportation. At the Wannsee Conference in 1942, Martin Luther acknowledged that the Jewish Problem would be difficult to handle in Scandinavia, and the deportations were postponed.222 By the end of that year, Nazi officials felt that the German Minister Plenipotentiary in Denmark was ineffective, and sent Dr. Werner Best as a replacement. Best had been handpicked for his tough character and SS background. In spite of this, he soon proved to be just as passive and sympathetic to the Jewish Problem in Denmark as his predecessor.

On September 9, 1943, Best became the effective dictator of Denmark, and ordered the initiation of deportation plans. Although Germany had taken over and discarded the idea of Samarbejdspolitik, Best knew that upsetting the Danish public could have serious political repercussions. Best consulted Hitler, via von Ribbentrop, about his secondthoughts on the deportations. When Best received confirmation that the deportation plans would continue, he began double-dealing. It is difficult to

222 Arendt, Eichmann in Jerusalem: A Report on the Banality of Evil, I70. 
rationalize Best's duplicity. One of the most plausible explanations is that he wanted to deemphasize his role as a perpetrator in the eyes of the Danes, in hopes of maintaining good relations with them, which would make his job easier. ${ }^{223}$ In line with this secret agenda, Best explained the details of the deportation to his confidant Georg Ferdinand Duckwitz, a shipping expert in the German Embassy. Duckwitz took this information to both Swedish officials and to Hans Hedtoft, the leader of the Danish Social Democrats. Because this information came straight from the perpetrators, Hedtoft could not dismiss it as a rumour. He alerted the leaders of the Jewish community, who in turn were able to warn the Jewish congregations in Copenhagen.

German collaboration was not limited to providing information. Duckwitz also advised the German commandant of the harbour in Copenhagen to send his speedboats in for repair, leaving very few patrol boats to monitor the Danish coastline. General Hermann von Hanneken (the commander of German forces in Denmark), was unwilling to supply troops for the deportation process, and reluctantly offered

223 For information on Best and his actions, see: Ibid., 173.; Raul Hilberg, The Destruction of the European Jews, 3ed. (New Haven and London: Yale University Press, 2003), 592-594.; Kirchhoff, Denmark: A Light in the Darkness of the Holocaust? A Reply to Gunnar S. Paulsson, 473.; Paulsson, The 'Bridge over the Oresund': The Historiography on the Expulsion of the Jews from Nazi-Occupied Denmark, 438.; Yahil, The Holocaust: The Fate of European Jewry, 1932-1945, 575. 
only 50 men to patrol the harbour. He also refused to force the Jews to report for "work duty" at the Wehrmacht offices, which forced the German police to search door-to-door. ${ }^{224}$ When the deportations began, Best would not even let the police break into Jewish apartments; they could only knock on the doors and catch people that were outside. Finally, Best asked his superiors for a guarantee that Nazi authorities would send all of the Jews in Denmark to Theresienstadt, regardless of their status as an assimilated Jew or an Eastern refugee. Although these Nazis were likely motivated out of self-interest and a desire to conserve relations with the Danes, their efforts are still admirable. As Yahil observes, it seems "that there hardly was one German left in Denmark who was prepared to execute the action against the Jews along the lines followed in others places."225 The indecisiveness and double-dealing of the Nazis made the rescue mission possible. Furthermore, the fact that the information about the deportation order came directly from the Nazis forced the Jews to accept that their lives were in danger and to take action.

224 Duckwitz and von Hanneken are described in Hilberg, The Destruction of the European Jews, 593-597.

225 The Rescue of the Danish Jews: Moral Courage Under Stress, 92. 
The deportation orders came at an opportune moment for the Danish Jews. The Danish political situation had encouraged the Germans in Denmark to delay deportation actions until 1943. By that time, rumours about the true meaning of Jewish "deportations" had spread throughout Europe. The Danes had learned that Norwegian Jews were being sent to camps in Germany and were determined to save their Jews from a similar fate. Furthermore, the course of the war was beginning to turn in favour of the Allies. News of Axis setbacks in Italy, the Pacific, Africa and the Eastern Front raised Danish hopes, and encouraged more open forms of resistance. Before 1943, the Danish resistance movement had been limited in size and relatively insignificant. However, German military failures, increasing food shortages and dock strikes caused more Danes to involve themselves in the resistance. $^{226}$ At the same time, neutral Sweden was changing its stance with Germany and with the Jews. The Swedish government ended an agreement with Germany which had permitted the German military passage through the country. In the days immediately preceding the deportation order in Denmark, the Swedish ambassador, Gustaf

226 Ibid., 37.; Friedman, Righteous Gentiles: Denmark and Norway, 319. 
von Dardel, also announced that Danish Jews would be offered sanctuary in Sweden. ${ }^{227}$

In retrospect, this series of world events that took place during 1943 was essential for the Jewish rescue. Increased awareness of German treatment of European Jews, Allied military advances and declining domestic conditions gave the Danes increased incentive to act, while developments in Sweden created an uncommon opportunity for the Danish Jews - a place of refuge. Had the deportation order come any earlier, the events of this rescue attempt may have unfolded very differently. However, it is important to recognize that timing was not a determinant on its own. For example, in Hungary, the Germans did not implement the Final Solution until March 1944, but they still managed to kill $50 \%$ of the Hungarian Jews by the end of the war. Norwegian Jews should have also had an advantage because their country shared a large border with Sweden, but an estimated $40 \%$ of Norwegian Jews died. ${ }^{228}$ The importance of timing in the Danish case should be considered in context with the other factors described, as none of these factors single-handedly determined the success of the rescue mission.

227 Arendt, Eichmann in Jerusalem: A Report on the Banality of Evil, 172.; The Rescue of the Danish Jews: Moral Courage Under Stress, 49.

228 Yahil, The Holocaust: The Fate of European Jewry, 1932-1945, 185.; Kirchhoff,

Denmark: A Light in the Darkness of the Holocaust? A Reply to Gunnar S. Paulsson, 466. 
The rescue of the Danish Jews involved more than a legend about the triumph of good over evil. It is dangerous to reduce it to a simple narrative with clear-cut heroes, victims and villains. The Danes were not all heroes, the Jews were not a united group, nor were the Germans purely evil.229 The complexity of the participating groups in the rescue of the Danish Jews implies that the success of this rescue cannot be solely attributed to the character of the Danes. Pre-existing circumstances and available opportunities determined the outcome of the Holocaust in occupied countries. In Denmark, the nature of the Danes and the Jews, the relative autonomy of the Danish government, the complicity of German officials and the timeframe for the deportation were all important factors in the rescue mission. Although some of these aspects were present in other occupied countries, it was only in Denmark that the various factors combined to facilitate the rescue of the Jews. An understanding of the complexities of the Danish case allows the historian to see through the romanticism of the rescue legend, and to better understand the substantive realities and dynamics of the event.

229 For a more sociological perspective on the group identities in wartime Denmark see: Buckser, Group Identities and the Construction of the 1943 Rescue of the Danish Jews, 217. 
Bibliography

The Rescue of the Danish Jews: Moral Courage Under

Stress. Edited by Leo Goldberger. New York: New York University Press, 1987.

Arendt, Hannah. Eichmann in Jerusalem: A Report on the Banality of Evil. 5th ed. New York: Penguin Classics, 1963.

Blüdnikow, Bent, and Vilhjálmur Örn Vilhjálmsson.

"Rescue, Expulsion, and Collaboration: Denmark's

Difficulties with its World War II Past." Jewish

Political Studies Review 18, no. 3.

Buckser, Andrew. "Group Identities and the Construction

of the 1943 Rescue of the Danish Jews." Ethnology 37, no. 3 (1998): 209-226.

Friedman, Saul S. "Righteous Gentiles: Denmark and Norway." In A History of the Holocaust. Middlesex, England: Vallentine Mitchell, 2004, 318-331.

Hilberg, Raul. The Destruction of the European Jews. 3rd ed. New Haven and London: Yale University Press, 2003.

Kirchhoff, Hans. "Denmark: A Light in the Darkness of the Holocaust? A Reply to Gunnar S. Paulsson." Journal of Contemporary History 30, no. 3 (1995): 465-479.

Leistikow, Gunnar. "Denmark Under the Nazi Heel."

Foreign Affairs 21, no. 2 (1943): 340-353.

Paulsson, Gunnar S. "The 'Bridge Over the Oresund': The Historiography on the Expulsion of the Jews from Nazi-Occupied Denmark." Journal of Contemporary History 30, no. 3 (1995): 431-464.

Wagner, Thorsten. "Belated Heroism: The Danish Lutheran Church and the Jews." In Antisemitism, Christian Ambivalence, and the Holocaust. Edited by Kevin P. Spicer. Bloomington, Indiana: Indiana University Press, 2007, 1-25. 
Yahil, Leni. The Holocaust: The Fate of European Jewry, 1932-1945. Translated by Ina Friedman and Haya Galai. New York and Oxford: Oxford University Press, 1990. 